\title{
CYP2C9*6 Allele
}

National Cancer Institute

\section{Source}

National Cancer Institute. CYP2C9*6 Allele. NCI Thesaurus. Code C46014.

Human CYP2C9*6 allele is located within $10 \mathrm{q} 24$ and is approximately $33 \mathrm{~kb}$ in leng th. This allele, a variant form of the CYP2C9 wild-type allele, encodes cytochrome P450 2C9*6 protein. The CYP2C9*6 allele exhibits a clinically-relevant SNP (c.818delA) in exon 5 that results in a coding frameshift. This alteration in protein sequence severely decreases the enzymatic activity of the cytochrome P450 2C9*6 protein. 